\title{
Solid Pseudopapillary Neoplasm of the Pancreas As a Rare Cause of Relapsing Acute Pancreatitis: A Case Report
}

\author{
Tekrarlayan Akut Pankreatitin Nadir Bir Sebebi Olarak Pankreasın Solid \\ Psödopapiller Neoplazm: Bir Olgu Sunumu
}

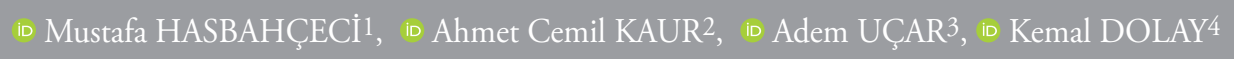

${ }^{1}$ Medical Park Fatih Hospital, Clinic of General Surgery, İstanbul, Turkey

2e-Pathology Laboratory, Pathology, İstanbul, Turkey

${ }^{3}$ LiV Hospital, Clinic of Radyology, İstanbul, Turkey

${ }^{4}$ LiV Hospital, Clinic of General Surgery, İstanbul, Turkey

\begin{abstract}
Solid pseudopapillary neoplasm of the pancreas is a rare tumor with low malignant potential. Although they are diagnosed incidentally, acute or relapsing pancreatitis in association with this tumor are reported rarely. A 22-year-old female patient was diagnosed with relapsing acute pancreatitis. Pseudocyst formation was identified based on imaging findings of a well-circumscribed cystic mass lesion located at the posterior aspect of the body and tail of the pancreas. At follow-up, extrapancreatic extension of a newly developed solid component was detected by imaging; thus, solid pseudopapillary neoplasm of the pancreas was suspected, and distal pancreatectomy with splenectomy was performed. Pathological examination revealed pancreatic mass lesion that was diagnosed as solid pseudopapillary tumor of the pancreas. This case implies that radical surgical resection should be the first treatment modality in all cases of solid pseudopapillary neoplasm of the pancreas. Even if typical imaging findings are present, co-occurrence of acute pancreatitis may cause diagnostic difficulty in some cases.
\end{abstract}

Keywords: Pancreatic neoplasm, solid pseudopapillary, acute pancreatitis

\section{ÖZ}

Pankreasın solid psödopapiller neoplazmı düşük malignite potansiyeli olan nadir bir tümördür. Genellikle rastlantısal olarak tanı konulmasına karşın, bu tümörle ilişkili akut veya tekrarlayan pankreatit nadiren bildirilmiştir. Yirmi iki yaşında kadın hasta tekrarlayan akut pankreatit ataklarılla değerlendirildi. Psödokist formasyonu olarak değerlendirilen, pankreas gövde ve kuyruk kesiminin posteriorunda yerleşmiş iyi sınırlı kistik kitle lezyonu görüntüleme bulguları ile teşhis edildi. İzlemde, ekstrapankreatik uzantısı olan yeni gelişmiş bir solid komponentin görüntüleme ile belirlenmesi üzerine, pankreasın solid psödopapiller neoplazmı ön tanısı ile distal pankreatektomi ve splenektomi yapıldı. Patolojik incelemede pankreasın solid psödopapiller tümörü olarak teşhis edilen pankreatik bir kitle lezyonu saptandı. Radikal cerrahi rezeksiyon, pankreasın tüm solid psödopapiller neoplazm olgularında ilk tedavi yöntemi olmalıdır. Tipik görüntüleme bulguları olmasına rağmen, akut pankreatitin birlikte görülmesi bazı durumlarda tanı zorluğuna neden olabilir.

Anahtar Sözcükler: Pankreatik neoplazm, solid psödopapiller, akut pankreatit

Address for Correspondence: Mustafa HASBAHÇECi, Medical Park Fatih Hospital, Clinic of General

Received: 24.01 .2020 Surgery, İstanbul, Turkey

E-mail: drhasbahceci@gmail.com ORCID ID: orcid.org/0000-0002-5468-5338

Accepted: 16.04 .2020

Cite this article as: Hasbahçeci M, Kau AC, Uçar A, Dolay K. Solid Pseudopapillary Neoplasm of the Pancreas As a Rare Cause of Relapsing Acute Pancreatitis: A Case Report. Bezmialem Science 2020;8(4):457-468. 


\section{Introduction}

Solid pseudopapillary neoplasms (SPNs) of the pancreas are rare tumors with low malignant potential and account for $2 \%-5 \%$ of all cystic neoplasms of the pancreas (1). Owing to the widespread use of pancreatic imaging with high-resolution techniques and increased familiarity of radiologists, surgeons, and pathologists, SPNs are increasingly detected in the recent decades. Most SPN cases are usually asymptomatic and diagnosed incidentally (2). However, SPN-associated acute or relapsing pancreatitis has been rarely reported (3-5). Although these tumors typically appear as large and well-circumscribed lesions, massive bleeding and extensive necrosis can be present within the compressed pancreatic tissues (6). Additionally, small tumors $(<3 \mathrm{~cm})$ without cystic component may be misdiagnosed as pancreatic cancer $(5,6)$. If these atypical features are present, differentiation from other pancreatic malignancies and inflammatory conditions may be difficult.

In this report, we aimed to present the case of a young female patient who was misdiagnosed with pancreatic pseudocyst following relapse of acute pancreatitis and finally diagnosed with SPN following surgical excision. Written consent was obtained from the patient for the publication of this case report.

\section{Case Report}

A 22-year-old female patient was assessed due to recurrent abdominal pain, nausea, and vomiting for the last 4 years. She had no history of abdominal trauma, gallstones, and alcohol and drug use. Previous bouts were evaluated by upper endoscopy and treated with proton pump inhibitors.

One year ago, she was diagnosed with acute pancreatitis, which was confirmed by increased levels of serum amylase and lipase. She received conservative treatment and consequently discharged uneventfully. Computed tomography (CT) and magnetic resonance imaging (MRI) were performed, and a well-circumscribed cystic mass lesion located at the posterior aspect of the body and tail of the pancreas was detected (Figure 1). Conservative management and close follow-up were recommended due to the radiological diagnosis of pseudocyst formation following a bout of acute pancreatitis. At 6 months after surgery, MRI showed a decrease in the diameter of the cystic mass, indicating regression of the pseudocyst (Figure 2).

At 1 year after surgery, she was re-admitted to our general surgery outpatient clinic with the same complaints. Results of the physical examination were normal, but mild epigastric tenderness was observed. Results of the laboratory analysis including serum amylase, serum lipase, carcinoembryonic antigen, and carbohydrate antigen 19-9 were also normal. MRI showed enhancement of a newly developed solid component of the mass after contrast administration (Figure 3). Extrapancreatic extension of the solid component was also observed. In view of these imaging findings, SPN of the pancreas was a possible diagnosis.
Surgical excision was planned on the basis of the imaging findings and progression of the pancreatic mass. Laparotomy was performed through bilateral subcostal incision, and a mass $(7 \mathrm{~cm}$ in diameter) that originated from the posterior aspect of the distal pancreas was detected. The mass was near the celiac trunk and the common hepatic artery. The splenic artery was surrounded by the lesion. Distal pancreatectomy with splenectomy was performed. A pancreatic fistula as a biochemical leak developed after the surgery. She was then discharged, but the drains were not removed. At two weeks after surgery, the fistula closed spontaneously.

A tight capsule was found during macroscopic examination. Solid, hemorrhagic, and cystic components were seen at the cross-sectional surface of the mass. Pathological examination revealed the pancreatic mass lesion ( $45 \mathrm{~mm}$ in diameter) that was diagnosed as a solid pseudopapillary tumor of the pancreas (Figure 4A). There was irregular arrangement of perivascular

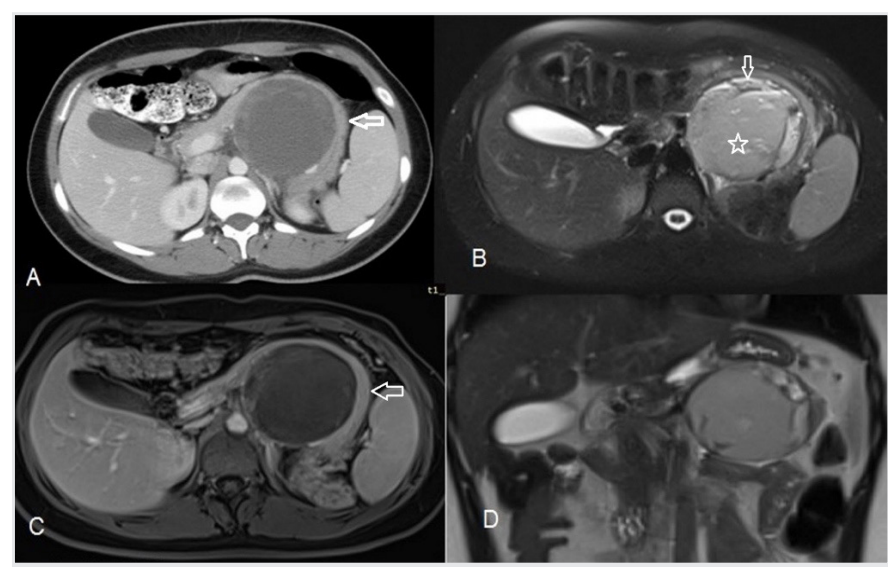

Figure 1. A) A well-circumscribed mass lesion located at the posterior aspect of the body and tail of the pancreas (arrow). No contrast enhancement at the anterior and medial walls of the cystic mass. B) Axial T2-weighted image showing a mass lesion with hypointense fluid signal within the center (star), layering debris, and mild early enhancement on the wall and septae (arrow). C) Axial T1-weighted image did not show contrast enhancement on the solid components of the mass (arrow). D) Coronal T2-weighted image
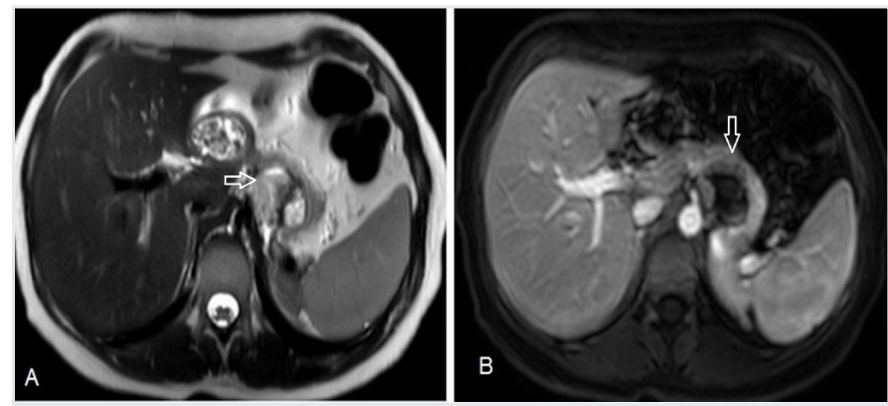

Figure 2. A) Axial T2-weighted image showing regression of the cystic mass (arrow). B) Portal phase contrast-enhanced axial T1-weighted image did not show septal or solid tissue contrast enhancement (arrow) 
pseudopapillary structures composed of fairly uniform tumor cells (Figure 4B, 4C). Peripancreatic, perineural, and lymphovascular invasions were not observed, and a total of 12 lymph nodes were involved. At 3 months after surgery, the patient had none of the previous complaints.

\section{Discussion}

After the first report by Lichtenstein in 1934 and description by Frantz in 1959, recent data have shown that SPN is a rare and slow-growing neoplasm of the pancreas $(3,7)$. Although its exact etiology is still unknown, several speculations include tumoral development of displaced cells from the ovarian genital ridge or from pluripotent embryonic cells under the influence of sex hormones (2-5).

SPN is usually found in female patients in their 20s or 30s (2, 3). The male-to-female ratio was nearly 1:10 (5). It has been also reported in male patients, pediatric patients, or patients aged $>50$ years (8). The present case involves a young female patient, which is consistent with previously published articles. Although most cases were reported as asymptomatic or nonspecific, mild abdominal pain without constitutive symptoms were detected in other patients. On the basis of previously published data, a typical patient is predominantly a young female patient with a large mass $(5-6 \mathrm{~cm}$ in average) and nonspecific abdominal symptoms $(2,5)$. Besides the presence of mild symptoms in these patients, cases of SPNs mimicking or coexisting with acute pancreatitis or pancreatic adenocarcinoma are rare, as in the present case (1, 3-5). Sakagami et al. (3) reported a female patient with SPN concomitant with acute pancreatitis. Chikuie et al. (5)

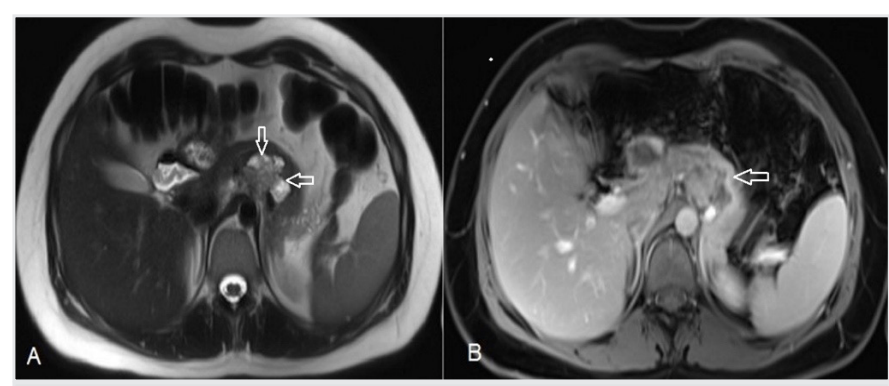

Figure 3. A) Axial T2-weighted image of a solid component of the mass (arrows). B) Venous phase contrast-enhanced T1-weighted image showing contrast enhancement of the mass with extrapancreatic extension (arrow)

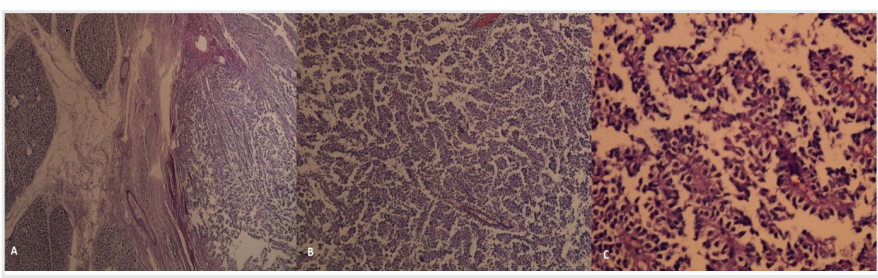

Figure 4. A) Well-circumscribed pancreatic tumor, demarcated from normally appearing pancreatic tissue at the left [hematoxylin and eosin (H\&E) staining, 40×]. B) Solid pseudopapillary tumor of the pancreas (H\&E, 100x). C) Pseudopapillary formations (H\&E, 400x) reviewed patients with both SPN and acute pancreatitis. They reported six cases where the tumors were located in the body or tail of the pancreas. Based on these reports, stenosis of the main pancreatic duct caused by SPN or any fibrous and degenerative changes around the tumor may be regarded as etiological factors. However, the exact mechanism of acute pancreatitis in patients with SPN remains unclear.

Although studies have reported equal distribution of tumors within the pancreas $(6,7)$, tumors most often occur in the body and tail, as in the present case $(2,8)$. SPN can be diagnosed by imaging techniques including CT and MRI (5). A large well-encapsulated mass with variable solid, hemorrhagic, and cystic components are typical CT findings of SPN. The most common features of SPN were round or oval-shaped mass with well-defined margins and slight hyperintensity on T1-weighted images, heterogeneous and hyperintense appearance on T2weighted images, and enhanced, slightly thickened capsule (6). If these features are present following a bout of acute pancreatitis, diagnosis might be difficult, causing a delay in differentiating pancreatic pseudocyst from SPN as in the present case. Therefore, SPN should be included in the differential diagnosis of all cystic pancreatic neoplasms.

On both CT and MRI, SPNs demonstrate well-defined margins and mixed solid and cystic appearance (6). However, the diagnosis can be difficult in some cases. Although small tumors $(<3 \mathrm{~cm})$ without cystic component can be misdiagnosed as pancreatic cancer, our case was diagnosed as SPN with nearly 1.5 years of delay even if imaging data were available $(5,6)$. History of acute pancreatitis and subsequent development of a probable pseudocyst might cause these diagnostic problems. However, slow mass growth and development of solid component can alert the attending physicians about the presence of SPN within the pancreas.

In suspicious cases in which SPN is not evident, endoscopic ultrasonography can be performed. In Karsenti's study (8), the sensitivity of endoscopic ultrasonography was $81 \%$. The use of both CT and endoscopic ultrasonography increases the detection of SPN. In the present case, the cystic lesion initially had hypointense fluid containing layering debris. Although endoscopic ultrasonography may be useful for the differentiation of SPN from other cystic lesions of the pancreas, due to the lack of such technology, we could not perform endoscopic ultrasonography.

Radical surgical resection with free resection margins is the standard treatment modality for SPN (2-5). Other adjuvant treatment modalities have no effect on the prognosis. Therefore, local tumor infiltration or metastatic disease should not be a contraindication for surgery, and radical resection should be chosen in all cases.

The World Health Organization has defined SPNs as indolent tumors with potentially malignant behavior (6). Metastasis due to SPN is rarely observed, and the 5-year survival rate can reach $100 \%$ (1). Malignancy rates can reach $12.3 \%$ considering 
the potential features of malignancy including capsular or parenchymal invasion, perineural invasion, angiovascular invasion, and nodal and liver metastases (6). However, in the absence of vascular and nerve sheath invasion or lymph node and liver metastases, other features are deemed controversial for a diagnosis of solid pseudopapillary carcinoma (2). In the present case, we thought that SPN was benign because all these features were absent. However, in Yepuri's report (9), 2.6\% of SPN cases recurred after more than 5 years of follow-up. Male sex, positive lymph nodes, R1 margins, and lymphovascular invasion were reported as significant risk factors for recurrence. Therefore, longer follow-up period is needed to clarify its potential malignant behavior.

The lack of immunohistochemical staining for beta catenin and E-cadherin and longer follow-up period were limitations of this case report. However, multiple CT and MR images showing the progression of SPN were essential to overcome potential diagnostic problems.

In conclusion, although SPN is a rare tumor with a favorable prognosis, radical surgical resection should be the initial treatment modality in all cases. Even if typical imaging findings are present, co-occurrence of acute pancreatitis may cause diagnostic difficulty in some cases.

\section{Ethics}

\section{Informed Consent: Obtained.}

Peer-review: Externally and internally peer reviewed.

\section{Authorship Contributions}

Surgical and Medical Practices: M.H., A.C.K., A.U., K.D., Concept: M.H., K.D., Design: M.H., K.D., Data Collection or Processing: M.H., A.C.K., A.U., K.D., Analysis or Interpretation: M.H., A.C.K., A.U., K.D., Literature Search: M.H., K.D., Writing: M.H., A.C.K., A.U., K.D.

Conflict of Interest: No conflict of interest was declared by the authors.

Financial Disclosure: The authors declared that this study received no financial support.

\section{References}

1. Chon HK, Choi KH, Kim TH. An Unusual Presentation of a Solid Pseudopapillary Tumor of the Pancreas Mimicking Adenocarcinoma. Clin Endosc 2019 Nov 22. doi: 10.5946/ce.2019.158.

2. Hansen CP, Kristensen TS, Storkholm JH, Federspiel BH. Solid pseudopapillary neoplasm of the pancreas: Clinical-pathological features and management, a single-center experience. Rare Tumors 2019;11:2036361319878513.

3. Sakagami J, Kataoka K, Sogame Y, Taii A, Ojima T, Kanemitsu $\mathrm{D}$, et al. Solid pseudopapillary tumor as a possible cause of acute pancreatitis. JOP 2004;5:348-52.

4. Belletrutti PJ, Allen PJ, Kurtz RC, DiMaio CJ. Education and imaging. Hepatobiliary and pancreatic: Recurrent pancreatitis caused by a solid pseudopapillary neoplasm of the pancreas. J Gastroenterol Hepatol 2011;26:787.

5. Chikuie E, Fukuda S, Tazawa H, Nishida T, Sakimoto H. A solid pseudopapillary neoplasm of the pancreas in a man presenting with acute pancreatitis: A case report. Int J Surg Case Rep 2017;31:114-8.

6. De Robertis R, Marchegiani G, Catania M, Ambrosetti MC, Capelli P, Salvia R, et al. Solid Pseudopapillary Neoplasms of the Pancreas: Clinicopathologic and Radiologic Features According to Size. AJR Am J Roentgenol 2019;213:1073-80.

7. Zou Y, Huang Y, Hong B, Xiang X, Zhou B, Wei S. Comparison of the clinicopathological features of pancreatic solid pseudopapillary neoplasms between males and females: gender does matter. Histol Histopathol 2019 Sep 3:18156. doi: 10.14670/HH-18-156.

8. Karsenti D, Caillol F, Chaput U, Perrot B, Koch S, Vuitton L, et al. Safety of Endoscopic Ultrasound-Guided Fine-Needle Aspiration for Pancreatic Solid Pseudopapillary Neoplasm Before Surgical Resection: A European Multicenter Registry-Based Study on 149 Patients. Pancreas 2020;49:34-8.

9. Yepuri N, Naous R, Meier AH, Cooney RN, Kittur D, Are C, et al. A systematic review and meta-analysis of predictors of recurrence in patients with Solid Pseudopapillary Tumors of the Pancreas. HPB (Oxford) 2019 Jul 23. pii: S1365-182X(19)30592-1. 